\title{
ARTIKELEN
}

\section{Recidive na verblijf in buitenlandse detentie}

\section{Een studie onder teruggekeerde gedetineerden in Nederland}

\author{
Matthias van Hall \& Laura Cleofa-van der Zwet
}

\section{Inleiding}

Nederlanders zitten niet enkel vast in penitentiaire inrichtingen in Nederland; jaarlijks zitten er minimaal 1900 Nederlanders vast in buitenlandse detentie. ${ }^{1}$ In vergelijking met andere landen heeft Nederland een relatief hoog aantal gedetineerden in buitenlandse detentie. ${ }^{2}$ De cijfers zijn gebaseerd op een peildatum (1 april), waardoor de groep Nederlanders per jaar in werkelijkheid groter is. Bijvoorbeeld in 2017 hebben er in totaal 3514 Nederlanders in het buitenland vastgezeten, terwijl er op peildatum 1 april 20171997 gedetineerden vastzaten. ${ }^{3}$ De aantallen zijn gebaseerd op alle Nederlanders die zich gemeld hebben voor (consulaire) bijstand en die in het bezit zijn van een Nederlands paspoort of identiteitskaart (of een vreemdelingenstatus of een verblijfsvergunning voor Nederland). ${ }^{4}$

Hoewel er steeds meer bekend is over Nederlandse gedetineerden in buitenlandse detentie en er in de afgelopen decennia meer dan honderd studies naar recidive zijn uitgevoerd in Nederland, ${ }^{5}$ is het onbekend in hoeverre Nederlandse gedetineerden na buitenlandse detentie recidiveren. Ze vormen een bijzondere groep. Ze hebben te maken met uiteenlopende detentieomstandigheden, de detentieduur is vaak langer, ze zijn ver weg van familie en vrienden en ze stromen vaak niet door naar de gangbare Nederlandse resocialisatieprogramma's. ${ }^{6}$ Omdat recidive van gedetineerden onwenselijk, schadelijk en duur voor de samenleving is, ${ }^{7}$ wordt er veel aandacht besteed aan het terugdringen ervan. Meer inzicht in reci-

1 Ministerie van Buitenlandse Zaken, De Staat van het Consulaire: Voor Nederland en Nederlanders wereldwijd, Den Haag: Ministerie van Buitenlandse Zaken 2019.

2 B. Vogelvang, I. Heemskerk \& H. Althoff, Geronseld, gegokt, gepakt en gesteund. De praktijk en de legitimering van het werk van Reclassering Nederland met in het buitenland gedetineerde Nederlanders, Den Bosch/Utrecht: Avans Hogeschool/Reclassering Nederland 2015.

3 Algemene Rekenkamer, Resultaten verantwoordingsonderzoek 2017 Ministerie van Buitenlandse Zaken (V), Den Haag: Algemene Rekenkamer 2018.

$4 \quad$ Ministerie van Buitenlandse Zaken 2019.

5 B.S.J. Wartna, D.L. Alberda \& S. Verweij, Wat werkt in Nederland en wat niet? Een meta-analyse van Nederlands recidiveonderzoek naar de effecten van strafrechtelijke interventies, Den Haag: WODC 2013.

6 F.B.A.M. Hofstee-van der Meulen, Detained abroad, Den Bosch: Uitgeverij BOXPress 2015; Vogelvang, Heemskerk \& Althoff 2015.

7 J. de Koning e.a., Kosten en baten van maatschappelijke (re)integratie van volwassenen en jeugdige (ex-)gedetineerden, Den Haag: WODC 2016. 
divecijfers is van belang voor alle organisaties die zich met Nederlanders in buitenlandse detentie bezighouden (waaronder het ministerie van Buitenlandse Zaken, Bureau Buitenland en Nederlandse gemeenten), om nog efficiënter te werken aan het verminderen van recidive. Jaarlijks keren er ongeveer 800 Nederlandse gedetineerden terug naar Nederland, ${ }^{8}$ maar in hoeverre weten ze een delictsvrij leven op te bouwen of gaan ze toch opnieuw de fout in? In dit onderzoek staan twee onderzoeksvragen centraal:

1 In hoeverre is er sprake van recidive onder teruggekeerde Nederlanders die in het buitenland hebben vastgezeten?

2 In hoeverre zijn de recidivecijfers van teruggekeerde Nederlanders die in het buitenland hebben vastgezeten gerelateerd aan verschillende achtergrondkenmerken (geslacht, leeftijd, detentieland, detentieduur, crimineel verleden en wijze van terugkeer)?

\section{Eerder onderzoek}

Hoewel beperkt van omvang, is er eerder onderzoek gedaan naar kenmerken van Nederlanders die in het buitenland vastzitten. ${ }^{9}$ Uit onderzoek naar het werk van Bureau Buitenland, onderdeel van Reclassering Nederland, bleek dat er jaarlijks gemiddeld 800 gedetineerden in het buitenland gedetineerd raken. ${ }^{10}$ Ander onderzoek liet zien dat Nederlanders voornamelijk vastzaten in Duitsland, Frankrijk en het Verenigd Koninkrijk. De meesten van hen waren mannen met een gemiddelde leeftijd van 41 jaar. Een groot deel van de Nederlanders die in het buitenland vastzaten, zo'n $83 \%$, zat vast vanwege een drugsdelict, $70 \%$ van de Nederlandse gedetineerden had schulden en $65 \%$ had geen beroepsonderwijs gevolgd of een diploma behaald. ${ }^{11}$ Een derde van de Nederlandse gedetineerden zat in buitenlandse detentie tot één jaar vast, gevolgd door een derde met een strafduur van één tot drie jaar, en een derde met een strafduur van langer dan drie jaar. ${ }^{12}$ Ter vergelijking: de meerderheid (73\%) van de gedetineerden in Nederland heeft drie maanden of korter vastgezeten. Nederlandse gedetineerden in buitenlandse detentie hebben dus vaker een langere strafduur. ${ }^{13}$

Onderzoek naar de invloed van consulaire bijstand door Nederlandse ambassades op de detentie-ervaring van 584 Nederlanders die in het buitenland vastzaten, heeft aandacht besteed aan (a) de noodzakelijke behoeften van Nederlandse gede-

8 Vogelvang, Heemskerk \& Althoff 2015.

9 Hofstee-van der Meulen 2015; J. Janssen, 'Nederlandse gedetineerden in het buitenland en de (on)mogelijkheden van het WOTS-verdrag, PROCES 2009, 2, p. 10-17; A.M. van Kalmthout, F.B.A.M. Hofstee-van der Meulen \& F. Dünkel, Foreigners in European Prisons, Nijmegen: Wolf Legal Publishers 2007; F. Miedema \& S. Stolz, Vast(gelopen) in den vreemde. Een onderzoek naar het hoge aantal Nederlanders in buitenlandse detentie, Den Haag: WODC 2008; E. Sikkens \& M. van San, 'Detentiebeleving en overleving van Nederlandse mulas in een Peruaanse gevangenis', Tijdschrift voor Criminologie 2012, 3, p. 232-246; Vogelvang, Heemskerk \& Althoff 2015.

10 Vogelvang, Heemskerk \& Althoff 2015.

11 Miedema \& Stolz 2008.

12 Hofstee-van der Meulen 2015.

13 Dienst Justitiële Inrichtingen, Gevangeniswezen, Den Haag: Dienst Justitiële Inrichtingen 2019. 
tineerden en (b) de terugkeer naar Nederland. De taalbarrière bij de communicatie tussen het gevangenispersoneel en de Nederlandse gedetineerden bleek een probleem te zijn. De meerderheid van de Nederlandse gedetineerden zei, tijdens de periode in buitenlandse detentie, dat de detentie-ervaring een belangrijke reden is om niet weer de fout in te gaan. Nagenoeg alle ondervraagde Nederlanders in het buitenland (90\%) verwachtten na het uitzitten van de straf terug te keren naar Nederland. Ze gaven aan behoefte te hebben aan het vinden van een huis en werk, het aanvragen van een uitkering en het regelen van officiële papieren. ${ }^{14}$

In buitenlandse detentie is er veelal sprake van gebrekkige sanitaire voorzieningen, slechte hygiëne, overvolle cellen en beperkte medische verzorging. ${ }^{15}$ De detentieomstandigheden verschillen per land en zijn bovendien afhankelijk van sociale, economische, politieke en culturele factoren. Het aanbod van arbeidsmatige, educatieve en sportieve activiteiten varieert tussen landen. De communicatie tussen Nederlandse gedetineerden en het gevangenispersoneel in buitenlandse detentie wordt bemoeilijkt door de taal- en cultuurbarrières. Gegeven de situatie dat men ver weg van vrienden en familie verblijft, is het voor Nederlandse gedetineerden moeilijk om contact te houden met de buitenwereld. ${ }^{16}$

\section{Begeleiding van Nederlandse gedetineerden en de wijze van terugkeer}

Er zijn verschillende organisaties betrokken bij de ondersteuning en begeleiding van Nederlandse gedetineerden in buitenlandse detentie. Zo zijn de ambassademedewerkers, werkzaam in opdracht van het ministerie van Buitenlandse Zaken, verantwoordelijk voor het bieden van consulaire bijstand aan Nederlanders die in het buitenland vastzitten. Daarnaast is de afdeling Internationale Overdracht Strafvonnissen (IOS), onderdeel van de Dienst Justitiële Inrichtingen (DJI), betrokken bij de Nederlandse gedetineerden die met de strafoverdracht terugkeren. Verder zijn er organisaties die juridische bijstand verlenen aan gedetineerden, namelijk PrisonLaw, Dutch\&Detained en Lawyers across Borders. Stichting Epafras biedt geestelijke ondersteuning aan Nederlandse gedetineerden. Tot slot is Bureau Buitenland betrokken. ${ }^{17}$

In dit onderzoek is er specifiek aandacht voor Nederlandse gedetineerden die bekend zijn bij Bureau Buitenland. De begeleiding van Bureau Buitenland vindt plaats in een vrijwillig kader, dat wil zeggen dat de gedetineerden zelf toestemming moeten geven voor het contact. Gedetineerden krijgen, na aankomst in buitenlandse detentie, de mogelijkheid om zich aan te melden voor begeleiding vanuit Bureau Buitenland. Zij komen in aanmerking voor begeleiding wanneer zij een Nederlands paspoort of verblijfsvergunning hebben. De werkwijze van

15 Hofstee-van der Meulen 2015; G. Vermeulen, A.M. van Kalmthout \& N. Paterson, Material detention conditions, execution of custodial sentences and prisoner transfer in the EU Member States, Antwerpen: Portland Maklu 2011.

16 Hofstee-van der Meulen 2015; Vogelvang, Heemskerk \& Althoff 2015.

17 Vogelvang, Heemskerk \& Althoff 2015. 
Bureau Buitenland is eerder beschreven, daarom zijn hierna de belangrijkste punten opgenomen. ${ }^{18}$

De begeleiding van Bureau Buitenland is erop gericht om de schadelijke effecten van buitenlandse detentie tegen te gaan en Nederlanders voor te bereiden op de terugkeer naar de Nederlandse samenleving. ${ }^{19}$ De kerntaak van Bureau Buitenland bestaat enerzijds uit humanitaire motieven, met aandacht voor de behoeften en noden van Nederlandse gedetineerden, en anderzijds uit reclasseringsmotieven, met als doel om recidive na vrijlating uit buitenlandse detentie te verminderen. Voorwaarde voor de begeleiding van Nederlandse gedetineerden die binnen Europa vastzitten, is dat ze voornemens zijn terug te keren naar Nederland. Omdat Bureau Buitenland ook werkt vanuit humanitaire motieven, is er in landen buiten Europa, waar de detentieomstandigheden over het algemeen slecht zijn, ook een beperkt aanbod voor Nederlandse gedetineerden die niet voornemens zijn terug te keren naar Nederland. Regiocoördinatoren (werkzaam in Utrecht) werken samen met vrijwilligers die woonachtig zijn in het land van detentie. De vrijwilligers bezoeken Nederlandse gedetineerden om de zes tot acht weken. De regiocoördinatoren onderhouden, indien gewenst, contact met het sociale netwerk van de gedetineerden en informeren en/of adviseren hen. Tijdens de begeleiding en bezoeken wordt er onder andere gewerkt aan het vergroten van het zelfinzicht en de zelfredzaamheid van de Nederlandse gedetineerde, aan het reflecteren op de periode voorafgaand aan de buitenlandse detentie en aan het inventariseren van leefgebieden waarop direct ingezet moet worden ter voorbereiding op de resocialisatie in Nederland. Bureau Buitenland begeleidt (Nederlandse) gedetineerden ongeacht de wijze waarop ze terugkeren naar Nederland. ${ }^{20}$ Nederlanders die in het buitenland vastzitten, kunnen op drie verschillende manieren terugkeren naar Nederland. De eerste manier is terugkeer door middel van strafoverdracht. ${ }^{21}$ Afhankelijk van het land waar de Nederlandse gedetineerde zich bevindt, is het sinds 1986 mogelijk om onder de voorwaarden zoals geformuleerd in de Wets ${ }^{22}$ en de Wots ${ }^{23}$ in aanmerking te komen voor het (gedeeltelijk) uitzitten van de buitenlandse straf in een Nederlandse gevangenis. Wanneer gedetineerden via strafoverdracht terugkeren, komen zij, net als gedetineerden in Nederland, in aanmerking voor de reguliere (nazorg)trajecten van de DJI, de gemeenten en de drie reclasseringsorganisaties (3RO). De begeleiding van Bureau Buitenland stopt op het moment dat gedetineerden in een Nederlandse penitentiaire inrichting geplaatst worden. De tweede manier om terug te keren is

18 M. Pape \& M. Brok, 'Werken met vrijwilligers bij Bureau Buitenland', PROCES 2020, 2, p. 133-135.

19 Vogelvang, Heemskerk \& Althoff 2015.

20 Pape \& Brok 2020.

21 Dienst Justitiële Inrichtingen, WOTS infoblad voor Nederlandse gevangenen in het buitenland, Den Haag: Dienst Justitiële Inrichtingen 2013; Dienst Justitiële Inrichtingen, WETS infoblad voor Nederlandse gevangenen in de EU, Den Haag: Dienst Justitiële Inrichtingen 2016.

22 De Wet Wederzijdse erkenning en tenuitvoerlegging vrijheidsbenemende en voorwaardelijke sancties (Wets) is bedoeld voor Nederlandse gedetineerden in de Europese Unie.

23 De Wet overdracht tenuitvoerlegging strafvonnissen (Wots) is gericht op gedetineerden in landen buiten de Europese Unie. 
met behulp van een overdracht van Bureau Buitenland naar de gemeentelijke nazorg (hierna 'overdracht' genoemd). De overdracht vindt plaats bij de Nederlandse gemeente waar de gedetineerde het laatst stond ingeschreven. ${ }^{24}$ Die gemeente is wettelijk verplicht om het nazorgtraject voor ex-gedetineerden vorm te geven. De nazorg is gericht op het op orde krijgen van huisvesting, arbeid/inkomen, schulden, zorg, sociaal netwerk én een identiteitsbewijs. ${ }^{25}$ De derde manier om terug te keren naar Nederland is door op eigen gelegenheid naar Nederland te reizen (hierna 'eigen kracht' genoemd). Bij deze groep is er geen sprake van een strafoverdracht, én Bureau Buitenland heeft geen overdracht gedaan bij een gemeente om nazorg of andere hulpverlening te faciliteren. Teruggekeerde Nederlanders kunnen zichzelf wel aanmelden bij de nazorgafdeling van de gemeente.

\section{Data en methode}

In het najaar van 2019 zijn er gegevens verzameld van Nederlandse gedetineerden die in $2015^{26}$ of 2016 zijn teruggekeerd uit buitenlandse detentie. Het gaat om personen (a) die in Nederland woonden, (b) die bekend waren bij Bureau Buitenland ten tijde van de buitenlandse detentie, (c) die van plan waren om na buitenlandse detentie terug te keren naar Nederland, en (d) van wie het digitale dossier bij Bureau Buitenland in 2016 is afgesloten. Op het moment dat iemand niet langer in buitenlandse detentie vastzat, is het dossier beëindigd. Bureau Buitenland is daarover geïnformeerd door de vrijwilliger in het land van detentie, door de ambassademedewerker of door een medewerker van de IOS indien er sprake was van strafoverdracht.

De dossiers kwamen uit het Integraal Reclassering Informatie Systeem (IRIS). De afdeling Statistische Informatievoorziening \& Beleidsanalyse (SIBA) van Reclassering Nederland heeft een lijst met gedetineerden aangeleverd. In totaal zijn er 968 unieke gedetineerden ${ }^{27}$ geselecteerd van wie de afsluitdatum van het dossier in 2016 of in de eerste twee maanden van 2017 ligt. ${ }^{28}$ Het Wetenschappelijk Onderzoek- en Documentatiecentrum (WODC) heeft van de gehele onderzoeksgroep gegevens aangeleverd over recidive en de criminele voorgeschiedenis. ${ }^{29}$

In totaal zijn er 278 gedetineerden verwijderd uit de onderzoeksgroep (a) omdat ze voor 2015 of na 2016 zijn teruggekeerd, terwijl het dossier in 2016 is afgeslo-

24 Vereniging van Nederlandse Gemeenten, Samenwerkingsmodel nazorg volwassen (ex-)gedetineerde burgers. Actualisatie 2011, Den Haag: Vereniging van Nederlandse Gemeenten 2011.

25 G. Weijters \& P.A. More, De monitor nazorg ex-gedetineerden: Ontwikkeling en eerste resultaten, Den Haag: WODC 2010.

26 Gedetineerden van wie het dossier in 2016 is afgesloten en die in 2015 zijn teruggekeerd, zijn meegenomen in de onderzoeksgroep omdat de verwachting was dat er ieder jaar een groep gedetineerden van soortgelijke grootte is van wie het dossier één jaar later is afgesloten.

27 Personen die zijn overleden in de periode van de recidivemeting zijn vooraf verwijderd.

28 De eerste twee maanden van 2017 zijn meegenomen omdat de datum van vrijlating bij gedetineerden buiten Europa veelal niet duidelijk is, met als gevolg dat het dossier begin 2017 is afgesloten.

29 Het WODC kan niet verantwoordelijk worden gehouden voor de volledigheid, correctheid en het gebruik van de verstrekte gegevens. 
ten $(N=144)$, of (b) vanwege het ontbreken van data in de Onderzoeks- en Beleidsdatabase Justitiële Documentatie (OBJD) $(N=134)$. Het dossier van sommige gedetineerden kon lang open blijven staan omdat er onduidelijkheid bestond over het moment van vrijlating of omdat er contact was met trajectrelevante instellingen. Redenen voor het ontbreken van OBJD-data kunnen zijn dat (a) de gedetineerden niet teruggekeerd zijn na buitenlandse detentie, (b) er administratieve fouten gemaakt zijn, (c) strafzaken geëindigd zijn in een algehele vrijspraak, in een technisch sepot of ontslag van rechtsvervolging of enkel kantonzaken omvatten, of (d) strafzaken enkel in het buitenland gepleegd zijn. $\mathrm{Na}$ uitsluiting van Nederlandse gedetineerden die buiten de onderzoeksgroep vielen en van wie geen OBJD-data bekend zijn, bestaat de onderzoeksgroep uit 690 personen.

Om te bepalen of er recidive heeft plaatsgevonden in Nederland is de definitie van recidive uit de WODC-recidivemonitor aangehouden. ${ }^{30}$ De strafrechtelijke recidive houdt in dat een individu een nieuw delict heeft gepleegd én is veroordeeld door de rechter of een afdoening van het Openbaar Ministerie heeft ontvangen. ${ }^{31}$ De recidive is gebaseerd op informatie uit de OBJD. Er was sprake van recidive als er een nieuwe veroordeling was geregistreerd tussen de startdatum en de einddatum van de follow-up periode (4 juli 2019). De observatieperiode vormde de tijd waarin de gedetineerden in het onderzoek zijn gevolgd; deze periode bestond uit minimaal 30 maanden (eind 2016 tot juli 2019: 30 maanden) en maximaal 55 maanden.

Voor de startdatum van de periode waarbinnen recidive wordt gemeten, is er in dit onderzoek onderscheid gemaakt tussen gedetineerden die in Europese landen hebben vastgezeten en gedetineerden die buiten Europa hebben vastgezeten. Voor alle gedetineerden in Europese landen was de einddatum van de detentie in het desbetreffende land de startdatum van de observatieperiode. De praktijk heeft geleerd dat gedetineerden in Europese landen binnen korte tijd naar Nederland terugkeren. Bij teruggekeerde (ex-)gedetineerden buiten Europa was de afsluitdatum van het dossier aangehouden als de begindatum van de observatieperiode. Bureau Buitenland heeft in de afgelopen decennia gezien dat gedetineerden uit landen buiten Europa niet in alle gevallen direct terug (kunnen) keren naar Nederland, bijvoorbeeld door het ontbreken van geld voor een vliegticket of een verplichting om na detentie een periode in het detentieland te verblijven.

De achtergrondkenmerken zijn gebaseerd op literatuur rondom recidive en praktijkkennis. ${ }^{32}$ Er zijn zo veel mogelijk onafhankelijke variabelen meegenomen die gerelateerd (kunnen) zijn aan recidive: detentieland, leeftijd (bij start recidivemeting), geslacht $(0=$ man, 1 = vrouw), wijze van terugkeer, detentieduur, aantal eerdere veroordelingen, aantal eerdere detentieperiodes, en leeftijd eerste strafzaak. De detentieduur betrof niet de strafmaat, maar het aantal maanden in

30 B.S.J. Wartna, M. Blom \& N. Tollenaar, De WODC-recidivemonitor, Den Haag: WODC 2011.

31 G. Weijters e.a., Recidive onder justitiabelen in Nederland: Verslag over de periode 2006-2018, Den Haag: WODC 2019.

32 P. Gendreau, T. Little \& C. Gogging, 'A meta-analysis of the predictors of adult offender recidivism: What works!, Criminology 1996, 4, p. 575-608. 
detentie, gebaseerd op de start- en einddatum detentie in het dossier in IRIS. De afdeling IOS heeft een lijst aangeleverd met gedetineerden die in 2016 via strafoverdracht (Wets/Wots) zijn teruggekeerd in Nederland. Om te bepalen welke teruggekeerde gedetineerden door Bureau Buitenland zijn overgedragen naar een Nederlandse gemeente, is er een registratie in het dossier in IRIS aangehouden. Echter, de gehanteerde registratie was niet waterdicht, daarom hebben de onderzoekers een digitale screening ${ }^{33}$ én een dossieronderzoek uitgevoerd om na te gaan of er daadwerkelijk een overdracht tussen Bureau Buitenland en een Nederlandse gemeente heeft plaatsgevonden. De teruggekeerde gedetineerden op eigen kracht vormen de groep die niet voorkomt in de registraties van de IOS noch in het dossier in IRIS.

Voordat de analyse is uitgevoerd, is het recidivepercentage bepaald. Voor elk halfjaar is het aantal gedetineerden berekend dat tot dan toe is gerecidiveerd. Vervolgens is dat aantal gedeeld door het totale aantal gedetineerden in de onderzoeksgroep (zie figuur 1).

Om het verband tussen een achtergrondkenmerk (bijvoorbeeld leeftijd) en recidive vast te stellen is gebruikgemaakt van survivalanalyse. Dit is een techniek die rekening houdt met verschillen in de observatieperiode, dus de tijd dat de personen in het onderzoek gevolgd kunnen worden. Er zijn diverse achtergrondkenmerken die worden getoetst, daarom wordt er gebruikgemaakt van de multiple Cox-regressie. ${ }^{34}$ Dit is een vorm van regressieanalyse waarbij een model wordt geconstrueerd dat een zo nauwkeurig mogelijke voorspelling geeft van de kans op recidive. Het model houdt rekening met het tijdstip waarop recidive plaatsvond en met de achtergrondkenmerken van gedetineerden. De hazard ratio (e $\beta$ ) toont de verhouding tussen het risico op recidive in de groep met een bepaald kenmerk en het 'normale' recidiverisico in de referentiegroep. Een hazard ratio groter dan 1 betekent een hogere kans op recidive ten opzichte van de referentiegroep; een hazard ratio kleiner dan 1 betekent een lagere kans op recidive. Hoe meer deze waarde (de hazard ratio) afwijkt van 1 , hoe groter de invloed van dit achtergrondkenmerk op de recidivekans. ${ }^{35}$

\section{Resultaten}

\section{Achtergrondkenmerken van Nederlanders in buitenlandse detentie}

Het merendeel van de 690 teruggekeerde Nederlandse gedetineerden uit buitenlandse detentie heeft in Europese landen vastgezeten (zie tabel 1). Nederlandse gedetineerden zijn veelal op eigen kracht teruggekeerd, gevolgd door de groep

33 In eerste instantie zijn er 265 gedetineerden met een 'aanmelding nazorg' bij een gemeente. $\mathrm{Na}$ de digitale screening blijken er 173 dossiers met de woorden 'nazorg' en/of 'gemeente'. Het dossieronderzoek heeft zich gericht op de 173 dossiers. Er is nagegaan of er sprake is van een overdracht tussen Bureau Buitenland en de gemeente en of de overdracht in 2016 heeft plaatsgevonden. In de overige 92 dossiers (zonder de woorden 'nazorg' en/of 'gemeente') is er weliswaar een aanmelding nazorg gedaan, maar er heeft geen overdracht plaatsgevonden van de regiocoördinator van Bureau Buitenland naar de nazorgafdeling.

34 P. Royston, 'Flexible alternatives to the cox-model, and more', The State Journal 2001, 1, p. 1-28. 
Tabel 1 Achtergrondkenmerken van de Nederlandse gedetineerden $(N=690)$

\begin{tabular}{lllllll}
\hline Variabele & N & $\%$ & Gem. & SD & Min. & Max. \\
\hline Detentieland & 188 & 27,2 & & & & \\
Duitsland & 99 & 14,3 & & & & \\
België & 73 & 10,6 & & & & \\
Groot-Brittannië & 70 & 10,1 & & & & \\
Frankrijk & 145 & 21 & & & & \\
Overige landen binnen Europa & 115 & 16,7 & & & & \\
Overige landen buiten Europa & 690 & & 40,87 & 12,07 & 18 & 78 \\
Leeftijd & 690 & &, 09 &, 286 & 0 & 1 \\
Geslacht (ref. = man) & & & & & & \\
Wijze van terugkeer & 155 & 22,5 & & & & \\
Strafoverdracht & 59 & 8,5 & & & & \\
Overdracht & 476 & 69 & & & & \\
Eigen kracht & 690 & & 26,61 & 25,47 & 1 & 168 \\
Detentieduur (in maanden) & 690 & & 6,86 & 10,59 & 0 & 133 \\
Aantal eerdere veroordelingen & 690 & & 1,62 & 3,32 & 0 & 40 \\
Aantal eerdere vrijheidsstraffen in & & & & & & \\
Nederland & 690 & & 24,86 & 10,93 & 12 & 68 \\
Leeftijd le strafzaak & & & & & & \\
\hline
\end{tabular}

met strafoverdracht en die met overdracht naar een Nederlandse gemeente. Nederlanders die vastzitten in buitenlandse detentie zijn vaak man en gemiddeld 41 jaar oud. De gemiddelde detentieduur in buitenlandse detentie is ongeveer 27 maanden. Ze zijn veelal geen first offenders. In Nederland hebben ze gemiddeld ongeveer zeven eerdere veroordelingen (mediaan is 4), en ongeveer de helft heeft minimaal één keer in Nederlandse detentie vastgezeten (52\%). De leeftijd bij de eerste strafzaak is gemiddeld 25 jaar (mediaan is 21 jaar).

Recidive onder Nederlandse gedetineerden uit buitenlandse detentie

Figuur 1 toont de ontwikkeling van het percentage gedetineerden die gerecidiveerd zijn in de observatieperiode. $\mathrm{Na}$ twee jaar is bijna een kwart (23\%) van de Nederlandse gedetineerden gerecidiveerd. In de totale observatieperiode is het recidivepercentage 29\%. Het recidivepercentage van 29\% staat dus voor 203 gedetineerden (van de 690 in totaal) die opnieuw veroordeeld zijn voor een delict/ strafbaar feit.

De invloed van achtergrondkenmerken op recidive in Nederland

Om meer zicht te krijgen op de achtergrondkenmerken die gerelateerd zijn aan de recidivekans onder Nederlandse gedetineerden is er een multivariate Cox-regressieanalyse uitgevoerd (zie tabel 2). De analyse berekent de kans op recidive en houdt tegelijkertijd rekening met de tijd tot recidive en de invloed van achtergrondkenmerken op recidive. 
Figuur 1 Het aantal maanden tot recidive onder gedetineerden uit buitenlandse detentie $(\%)(N=690)$

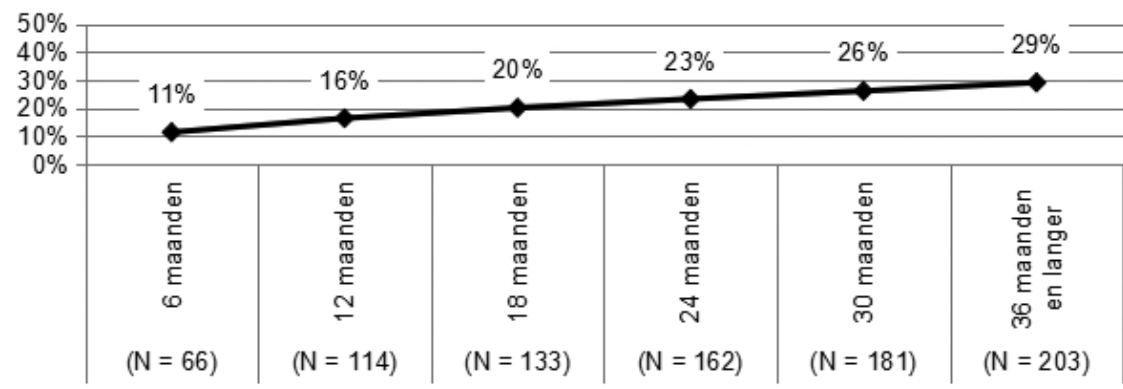

Noot: De N toont het totaal aantal gedetineerden die tot dat moment gerecidiveerd zijn.

Het blijkt dat de recidivekans kleiner is als een Nederlandse gedetineerde via strafoverdracht is teruggekeerd dan wanneer een Nederlandse gedetineerde op eigen kracht terugkeert. Daarnaast is de recidivekans kleiner als de Nederlandse gedetineerde ouder is op het moment dat hij (of zij) uit buitenlandse detentie komt. In andere woorden, naarmate de leeftijd van de gedetineerde stijgt, wordt de recidivekans kleiner. Verder is de recidivekans kleiner voor een Nederlandse gedetineerde die in overige landen binnen Europa, zoals Spanje of Zweden, heeft vastgezeten dan voor gedetineerden die in België hebben vastgezeten. Ten slotte is de recidivekans groter als de Nederlandse gedetineerde eerder een vrijheidsstraf in Nederland heeft uitgezeten. De overige achtergrondkenmerken, bijvoorbeeld de detentieduur of de leeftijd van het eerste justitiecontact, blijken in dit model niet van invloed op de recidivekans.

\section{Conclusie}

Uit deze studie is gebleken dat $23 \%$ van de 690 Nederlandse gedetineerden binnen twee jaar na vertrek uit buitenlandse detentie in aanraking is geweest met justitie naar aanleiding van een strafbaar feit. Na meer dan drie jaar is het recidivepercentage $29 \%$. Nederlandse gedetineerden vormen een unieke groep, gezien de detentieomstandigheden en de detentieduur in het buitenland, de afstand tot familie en vrienden én de wijze waarop ze resocialiseren in de Nederlandse samenleving. Nederlanders die in het buitenland vastzitten, verblijven veelal in Europese landen, ze keren vaak op eigen kracht terug naar Nederland en hebben een gemiddelde leeftijd van 41 jaar. Gemiddeld genomen zijn ze eerder veroordeeld en hebben ze eerder vastgezeten in Nederland.

Als deze cijfers vergeleken worden met de tweejarige recidiveprevalentie van gedetineerden die in Nederland hebben vastgezeten, valt op dat Nederlandse gedetineerden in buitenlandse detentie minder recidiveren. Nederlanders die in Nederland hebben vastgezeten voor een periode van twee tot vier jaar (43\%) of 
Tabel 2 Cox-regressieanalyse voor de invloed van achtergrondkenmerken op recidive in Nederland in de gehele observatieperiode $(N=690)$

\begin{tabular}{lll}
\hline Variabele & e $\beta$ & SE \\
\hline Detentieland (referentiecategorie = België) & &, 202 \\
Duitsland &, 694 &, 262 \\
Groot-Brittannië &, 750 &, 279 \\
Frankrijk &, 625 &, 247 \\
Overige landen binnen Europa &, $531^{* *}$ &, 268 \\
Overige landen buiten Europa &, 599 &, 009 \\
Leeftijd (in jaren) &, $953^{* * *}$ &, 272 \\
Geslacht (ref. = man) &, 851 & \\
Wijze van terugkeer (ref.= eigen kracht) & &, 250 \\
Strafoverdracht &, $339 * * *$ &, 304 \\
Overdracht &, 595 &, 071 \\
Detentieduur (in maanden) & 1,031 &, 011 \\
Aantal eerdere veroordelingen & 1,003 &, 039 \\
Aantal eerdere vrijheidsstraffen in Nederland & $1,104^{*}$ &, 010 \\
Leeftijd le strafzaak & 1,010 & \\
\hline
\end{tabular}

NB: -2 Log Likelihood = 2434,52 I; Chi-square = I I8,577***.

$*$ p. $<, 05 ; * *$ p. $<, 01 ; * * *$ p. $<, 001$.

meer dan vier jaar (32\%) recidiveren gemiddeld genomen vaker. ${ }^{36}$ Verder lijkt de tweejarige recidiveprevalentie hoger te liggen onder ex-gedetineerden (47\%) en ex-ondertoezichtgestelden (36\%) in Nederland dan onder Nederlanders die in het buitenland hebben vastgezeten. ${ }^{37}$ Nader onderzoek is nodig om een mogelijk verschil in recidiveprevalentie te toetsen.

Ook is nader onderzoek nodig om het recidivepercentage te verklaren. Er kan gedacht worden aan factoren als leeftijd, de begeleiding tijdens detentie en/of de impact van de detentieomstandigheden. Nederlandse gedetineerden in buitenlandse detentie zijn gemiddeld 41 jaar oud en ouder dan gedetineerden in Nederland (gemiddeld 37 jaar in 2017). ${ }^{38}$ De leeftijd-criminaliteitscurve (ook wel bekend als de age-crime-curve) geeft weer dat het aantal delicten vanaf de adolescentie oploopt en een piek kent in het midden van de 20, waarna er een geleidelijke daling plaatsvindt. Dit suggereert dat de kans op recidive kleiner wordt wanneer gedetineerden de leeftijd van 25 tot 30 zijn gepasseerd. ${ }^{39}$ Daarnaast kan het begeleidingsaanbod van Bureau Buitenland en andere organisaties de recidi-

36 Deze gegevens zijn te vinden in REPRIS via www.wodc.nl/onderzoek/cijfers-en-prognoses/ Recidive-monitor/repris/.

37 Weijters e.a. 2019.

38 J. de Looff e.a., DJI in getal 2013-2017, Den Haag: Dienst Justitiële Inrichtingen 2018.

39 J.H. Laub \& R.J. Sampson, Shared beginnings, divergent lives, Cambridge: Harvard University Press 2003; B.S.J. Wartna \& N. Tollenaar, Recidive 1997-2003: Ontwikkelingen in het niveau van de strafrechtelijke recidive, Den Haag: WODC 2006. 
vekans verkleinen. Alle Nederlandse gedetineerden in deze studie zijn immers korte of langere tijd begeleid door Bureau Buitenland. Tijdens de begeleiding wordt het sociale netwerk van de Nederlandse gedetineerde in buitenlandse detentie actief betrokken. Eerder onderzoek laat zien dat gedetineerden na vrijlating terugvallen op het (prosociale) netwerk en dat een (pro)sociaal netwerk de kans op recidive na vrijlating kan verkleinen. ${ }^{40}$ Ten slotte is het mogelijk dat een detentie in het buitenland een afschrikwekkend(er) effect heeft op de gedetineerden, gezien de vaak minder prettige omstandigheden in buitenlandse detentie. Eerder hebben Nederlanders aangegeven dat de detentie-ervaring in het buitenland een belangrijke reden is om niet meer de fout in te gaan. ${ }^{41}$ Hoewel dit argument voornamelijk betrekking heeft op de omstandigheden in buitenlandse detentie, is er wellicht een neveneffect op detentie in het algemeen. De criminologische literatuur vindt overigens tot op heden weinig ondersteuning voor een afschrikwekkend effect van zwaardere straffen. ${ }^{42}$

Enkele achtergrondkenmerken verkleinen of vergroten de kans op recidive. Nederlandse gedetineerden die met strafoverdracht zijn teruggekeerd, hebben een kleinere recidivekans dan gedetineerden die op eigen kracht terugkeren. Wellicht weten gedetineerden met strafoverdracht de weg naar reguliere zorgtrajecten beter te vinden, waardoor ze met begeleiding het laatste zetje kunnen ontvangen om een pad zonder criminele activiteiten te vinden. Daarnaast blijkt dat de kans op recidive kleiner wordt naarmate Nederlandse gedetineerden ouder worden. Dit is in lijn met wat bekend is vanuit eerder (inter)nationaal onderzoek. ${ }^{43}$ Verder hebben Nederlandse gedetineerden in overige landen binnen Europa een kleinere kans om te recidiveren dan gedetineerden in België. Het is (nog) onduidelijk hoe dit verschil te verklaren is. Tot slot hebben Nederlandse gedetineerden een grotere kans om te recidiveren wanneer ze eerdere vrijheidsstraffen hebben uitgezeten. Bestaand onderzoek laat zien dat eerdere vrijheidsstraffen samenhangen met recidive. ${ }^{44}$

Er zijn vier belangrijke beperkingen van deze studie aan te wijzen. Ten eerste is het lastig om te toetsen hoe representatief deze data zijn. Het blijft onduidelijk hoe groot de totale groep Nederlanders is die in het buitenland vastzitten, omdat het ministerie van Buitenlandse Zaken enkel de personen met consulaire bijstand telt. ${ }^{45}$ Bureau Buitenland is grotendeels afhankelijk van de informatie van het ministerie en begeleidt niet alle Nederlandse gedetineerden in het buitenland.

40 J.C. Cochran, 'Breaches in the wall: Imprisonment, social support, and recidivism', Journal of Research in Crime and Delinquency 2014, 2, p. 287-301; F.T. Cullen, 'Social support and crime', in: F.T. Cullen \& R. Agnew (red.), Criminological Theory: Past to Present, New York: Oxford University Press 2011, p. 590-596.

41 Hofstee-van der Meulen 2015.

42 T.A. Loughran e.a., 'Estimating a dose-response relationship between length of stay and future recidivism in serious juvenile offenders', Criminology 2009, 3, p. 699-740; G.M. Snodgrass e.a., 'Does the time cause the crime? An examination of the relationship between time served and reoffending in the Netherlands', Criminology 2011, 4, p. 1149-1194.

43 Gendreau, Little \& Gogging 1996; Wartna \& Tolenaar 2006.

44 Gendreau, Little \& Gogging 1996.

45 Ministerie van Buitenlandse Zaken 2019. 
Een schatting is dat Bureau Buitenland ongeveer $60 \%$ van alle Nederlanders bereikt. ${ }^{46}$ Ten tweede is de observatieperiode van Nederlandse gedetineerden die met strafoverdracht zijn teruggekeerd waarschijnlijk korter. Deze groep is in 2016 teruggekeerd met strafoverdracht en heeft daarna een deel van de buitenlandse straf in Nederlandse penitentiaire inrichtingen uitgezeten. De periode om te recidiveren is voor Nederlandse gedetineerden met strafoverdracht dus vermoedelijk korter. Er bestaat ook onduidelijkheid over de start van de observatieperiode voor deze groep, omdat het strafrestant niet altijd bekend was en deze gedetineerden, onder voorwaarden, in aanmerking kwamen voor vervroegde invrijheidstelling. Ten derde is het meten van recidive beperkt. Nederlanders kunnen namelijk ook lang in het buitenland vastzitten op verdenking van een delict. Als het strafproces leidt tot vrijspraak of een sepot en de persoon niet eerder in aanraking is gekomen met justitie in Nederland, dan is er strikt genomen geen sprake van recidive, maar van een nieuw justitieel contact. Bovendien is recidive - net als in bestaand recidiveonderzoek van het WODC - gemeten op basis van registratiegegevens en heeft dus betrekking op enkel criminaliteit die onder de aandacht komt van het Openbaar Ministerie en leidt tot een strafzaak. Ten vierde is niet geheel duidelijk of gedetineerden uit buitenlandse detentie daadwerkelijk zijn teruggekeerd naar Nederland. Om begeleiding van Bureau Buitenland te ontvangen moeten gedetineerden van plan zijn om terug te keren naar Nederland. Ongeveer $90 \%$ van de Nederlandse gedetineerden verwacht terug te keren naar Nederland. ${ }^{47}$ Echter, wanneer men niet is teruggekeerd, is het uitblijven van recidive logisch te verklaren. Als er minder gedetineerden teruggekeerd zijn naar Nederland, is het recidivepercentage onderschat.

De belangrijkste kracht van de huidige studie is dat ze, in samenwerking met de werkpraktijk, aandacht besteedt aan een bijzondere doelgroep waarvan het recidivepercentage tot op heden onbekend was. Dit is gedaan aan de hand van unieke data, waardoor van alle gedetineerden in deze studie gedetailleerde achtergrondinformatie bekend was over de periode van detentie, de wijze van terugkeer én de recidive in Nederland.

\section{Tot slot}

In deze studie is de recidiveprevalentie onderzocht onder Nederlandse gedetineerden die in buitenlandse detentie hebben vastgezeten. De resultaten laten zien dat $23 \%$ van deze groep binnen twee jaar recidiveert. Hoewel dit onderzoek een belangrijke eerste beschrijving van de recidive bij deze groep geeft, roept het vragen voor vervolgonderzoek op, zoals: hoe verhoudt de recidive bij deze bijzondere groep zich tot recidivecijfers bij goed vergelijkbare controlegroepen, zoals gedetineerden in Nederland? Bovendien vragen de cijfers om een nadere kwalitatieve duiding door de gedetineerden zelf te bevragen: hoe hebben zij hun buitenlandse detentie en de terugkeer naar Nederland ervaren? Deze verhalen en 
ervaringen bieden een waardevolle aanvulling bij het verklaren of nuanceren van de gevonden uitkomsten. Op deze manier kunnen toekomstige studies een bijdrage leveren aan het streven om de recidive onder Nederlandse gedetineerden die na hun buitenlandse detentie naar Nederland terugkeren, terug te dringen. 